\title{
Influence of Jet-Cooking Corn Bran on Its Antioxidant Activities, Phenolic Contents and Viscoelastic Properties
}

\author{
George E. Inglett, Diejun Chen, Mark Berhow
}

USDA, Agricultural Research Service, National Center for Agricultural Utilization Research, Functional Foods Research Unit, Peoria, USA.

Email: George.Inglett@ars.usda.gov

Received April 29 $9^{\text {th }}, 2011$; revised May 28 $8^{\text {th }}, 2011$; accepted June $6^{\text {th }}, 2011$.

\begin{abstract}
Corn bran was subjected to high-shear and jet-cooking with or without alkaline treatment. The highest antioxidant activity was found in the soluble solids from jet-cooked corn bran without alkaline treatment. Jet-cooking under alkaline conditions resulted in a soluble fraction having the highest phenolic content but without increasing antioxidant activity. Phenolic contents of soluble solids were significantly higher than the insoluble solids. A colorimetric method using spectrophotometer was suitable to determine total phenolic content, whereas LC-ESI-MS technology was used for identifying important individual phenolic acids, namely caffeic, coumaric and ferulic acid. The insoluble solids from alkaline treatment had the highest water holding capacity and interesting viscoelastic properties. These results suggested that jet-cooking corn bran may be a useful processing procedure for creating phytochemical and functional products.
\end{abstract}

Keywords: Corn Bran, Phenolic Contents, Antioxidant Activity, Jet-Cooking, Water Holding Capacity, Viscoelastic Properties

\section{Introduction}

Corn bran has received a renewed interest as a phytochemical source. Recent studies found that corn bran contain polyamine conjugates and related hydroxycinnamic acids [1,2]. Corn bran is also rich in several functional lipid constituents, including unsaturated fatty acids, tocopherols and phytosterols, and dietary fiber and carotenoid pigments [3]. Corn bran contains ferulic acid which has bioactivity related to the medicinal functions of $R$. A. sinensis, one of the most commonly used traditional Chinese medicine [4]. Traditional extraction method for ferulic acid was to reflux $R$. A. sinensis for $4-5$ $\mathrm{h}$ in $70 \%$ ethanol [5].

Corn bran fiber can provide a good source of dietary fiber. Women with high intake of cereal fiber showed a $34 \%$ lower risk of coronary heart disease events when compared to women with low cereal fiber intake [6]. Cereal dietary fiber may produce these effects through multiple physiological mechanisms that include binding and eliminating cholesterol, modulation of hormonal activity, stimulation of immune system, and facilitating toxicant transit through the digestive tract. A two-step fractionation process with enzymatic hydrolysis effectively enriched arabinoxylan content [7]. Corn fiber gum (CFG) can be obtained by the extraction of corn bran using an alkaline hydrogen peroxide process [8].

This research was conducted to explore pro-cessing techniques for enhancing the bioactive and physical properties of corn bran for human health benefits and increasing its market value. The influence of jet-cooking and alkaline treatments on corn bran fractions was studied for phenolic contents, antioxidant activities, and physical properties of the fractions.

\section{Materials and Methods}

\subsection{Source of Corn Bran}

Corn bran used in this study was supplied by Bunge Milling Company (Danville, IL).

\subsection{Processing Procedures}

This procedure was modified from previous experience with corn bran by degrading and dispersing cellular 
components into soluble and insoluble portions [9-12].

\subsubsection{Jet-Cooking with Alkaline Treatment (T1)}

1) Three-hundred grams of corn bran and $15 \mathrm{~g}$ of lime ( $\mathrm{CaO}$, Sigma) were gradually added to $1.2 \mathrm{~L}$ of hot water $\left(80^{\circ} \mathrm{C}\right)$, and mixed using a Polytron (PT6000, Kinematica AG, Littau, Switzerland) at $8000 \mathrm{rpm}$ for $5 \mathrm{~min}$. The $\mathrm{pH}$ was adjusted to 12 with $50 \%$ sodium hydroxide, and mixed at again $8000 \mathrm{rpm}$ for 5 another min.

2) The slurry was mixed with $1.5 \mathrm{~L}$ water, and then jet-cooked (Penford Corp., Cedar Rapids, IA) at 65 psi, $140^{\circ} \mathrm{C}$, and $1.2 \mathrm{~L} / \mathrm{min}$ flow rate. The slurry was jet-cooked a second time, and $\mathrm{pH}$ was adjusted to 7 with acetic acid, and followed by centrifugation at $3000 \mathrm{rpm}(1500 \mathrm{~g})$ for $15 \mathrm{~min}$.

3) The supernatant and insoluble fractions were drumdried at $135^{\circ} \mathrm{C}$ (Model 20; Drum Dryer and Flaker Company, South Bend, IN), and then ground to pass through a $150 \mu \mathrm{m}$ (100 mesh) sieve using a grind (Fritsch, Serial No. 14.102/2196, Idar-Oberstein, Germany).

\subsubsection{Jet-Cooking without Alkaline Treatment (T2)}

T2 was treated the same as T1 except no alkaline treatment made before jet-cooking.

\subsubsection{Control (TC)}

The unprocessed corn bran was used as control compared to jet-cooked treatments.

\subsection{Proximate Composition}

Moisture contents were determined according to approved method 44 - 15.02 [13]. Protein was determined by the combustion method with a protein correction factor of $\% \mathrm{~N} \times 6.25$ [14]. Oil was extracted using a Soxhlet apparatus and quantified gravimetrically [15]. Ash was determined gravimetrically after combustion at $590^{\circ} \mathrm{C}$ for $12 \mathrm{~h}$ (Thermolyne, Sybron Corp., Milwaukee, WI, USA).

\subsection{Total Phenolic Contents and Antioxidant Activity}

\subsubsection{Sample Extraction}

One-hundred $\mathrm{mg}$ of corn bran or treated bran fractions was suspended in $10 \mathrm{~mL}$ of water, $10 \%$ ethanol, $50 \%$ ethanol, and $2 \%$ calcium hydroxide respectively, and mixed on a vortex mixer. Tubes were then placed in a boiling water bath for $5 \mathrm{~min}$, and then centrifuged at $1500 \mathrm{~g}$ for $10 \mathrm{~min}$. The supernatant was analyzed for phenolics content and antioxidant activity.

\subsubsection{Total Phenolic Content Using Colorimetric Method}

Total phenolic content was determined by the FolinCiocalteau colorimetric method as described pre-viously with minor modifications [16,17]. To $100 \mu \mathrm{L}$ of extract, $7.9 \mathrm{~mL}$ of deionized water and $0.5 \mathrm{~mL}$ of Folin-Ciocal- teau reagent (Sigma Aldrich, St Louis, MO) were added, mixed on a vortex mixer, and $1.5 \mathrm{~mL}$ of $1.85 \mathrm{M} \mathrm{Na}_{2} \mathrm{CO}_{3}$ added after $15 \mathrm{~min}$. Absorbance of samples was measured at $765 \mathrm{~nm}$ wavelength after $2 \mathrm{~h}$ using gallic acid as a standard. Results were expressed as $\mathrm{mg}$ of gallic acid equivalents per $\mathrm{g}$ of sample on dry basis.

\subsubsection{Antioxidant Activity Measurements}

Antioxidant activities were determined as described with modifications by reacting $1 \mathrm{~mL}$ of the extracts with $1 \mathrm{~mL}$ of $200 \mu \mathrm{M}$ 2,2-diphenyl-1-picryl-hydrazyl (DPPH) [18, 19]. Absorbance was measured at $515 \mathrm{~nm}$ wavelength after a 40 min reaction in dark. Tubes were centrifuged for $10 \mathrm{~min}$ at $3000 \mathrm{rpm}(\mathrm{X} 1462 \mathrm{~g}$ ) prior to reading the absorbance at $515 \mathrm{~nm}$. Results were expressed as $\mu \mathrm{M}$ of 6-hydroxy-2,5,7,8-tetramethylchroman-2-carboxylic acid (Trolox) equivalents per $\mathrm{g}$ of sample on dry basis.

\subsection{Identification of Phenolic Acid Using LC-ESI-MS Analysis}

\subsubsection{Sample Extraction}

Samples $(250 \mathrm{mg})$ were mixed with $3 \mathrm{~mL}$ of methanol, capped, wrapped with sealing tape, and incubated for 72 $\mathrm{h}$ at room temperature. Samples were then sonicated for $15 \mathrm{~min}$ at $25^{\circ} \mathrm{C}$ and allowed to stand at room temperature for $1-2 \mathrm{~h}$. An aliquot was removed from the vial and filtered $(0.45 \mu \mathrm{m})$ for HPLC analysis.

\subsubsection{Analytical Methodology}

The method used was similar with a previous method [20]. Samples were run on a stand-alone Shimadzu 10A HPLC system (SCL-10A system controller, two LC-10A pumps, CTO-10A column oven, and SIL-10A autoinjector). Peaks were monitored using a Hewlet-Packard $1040 \mathrm{~A}$ photodiode array detector running under the HP Chemstation software version A.02.05. The column used was an Inertsil ODS-3 reverse phase C-18 column $(5 \mu \mathrm{M}$, $250 \times 4.6 \mathrm{~mm}$, with a Metaguard guard column, from Varian). For phenolic analysis, the initial conditions were $20 \%$ methanol and $80 \% 0.01 \mathrm{M}$ phosphoric acid in water, at a flow rate of $1 \mathrm{ml}$ per min. The effluent was monitored at $285 \mathrm{~nm}$ on the VWD. After injection (typically $15 \mu \mathrm{L}$ ), the column was held at the initial conditions for $2 \mathrm{~min}$, then developed to $100 \%$ methanol in a linear gradient over $53 \mathrm{~min}$. Three point standard curves based on nanomoles injected were prepared from injections of pure standards of coumaric acid, caffeic acid, sinapic acid and ferulic acid obtained from Sigma Chemical Co (St. Louis, MO).

\subsubsection{LC-ESI-MS Analysis}

Samples were run on a Finnigan-Thermoquest LCQ LC-MS system (AS3000 autoinjector, P4000 HPLC pump, UV6000 PDA detector, LCQ ion-trap mass spec- 
trometer and a nitrogen generator) (San Jose, CA) all running under the Xcaliber 1.3 software system. The MS was run with the ESI probe in the negative mode. The column was a $3 \mathrm{~mm} \times 150 \mathrm{~mm}$ Inertsil reverse phase C-18, ODS 3, $3 \mu$ column (Metachem, Torrance, CA) with a Metaguard guard column. The source inlet temperature was set at $300^{\circ} \mathrm{C}$ and the sheath gas rate was set at 80 arbitrary units. The MS was optimized for the detection of phenolic acids by using the autotune feature of the software while infusing a solution of ferulic acid in with the effluent of the column and tuning on an atomic mass unit of $193[\mathrm{M}-\mathrm{H}]^{-}$. The solvent systems included A (water with $0.25 \%$ acetic acid) and B (methanol with $0.25 \%$ acetic acid). The column was equilibrated with $20 \% \mathrm{~B}$ at a flow rate of $0.3 \mathrm{ml}$ per min. After injection the column was held at the initial conditions for $2 \mathrm{~min}$, and then developed with a linear gradient to $100 \% \mathrm{~B}$ over $50 \mathrm{~min}$. The column effluent was monitored at 285 $\mathrm{nm}$ in the PDA detector. The software package was set to collect mass data between 150 - 1000 AMUs. Generally the most significant sample ions generated under these conditions were $[\mathrm{M}-\mathrm{H}]^{-}$.

\subsection{Water-Holding Capacity}

The method for water-holding capacity of corn bran and its fractions was modified according to a previous procedure [21]. Solids $(2 \mathrm{~g})$ with or without jet-cooking were mixed with $25 \mathrm{~g}$ of deionized water and vigorously mixed using a vortex to make a suspension, allowed to stand for $2 \mathrm{~h}$, followed by centrifugation at $1,462 \mathrm{~g}$ for 15 $\min$. The supernatant was decanted and weight of residue was measured. The water-holding capacity for each sample was measured in duplicate. Water-holding capacity was calculated by the following equation:

water holding capacity $(\%)=($ sample weight after centrifugation-dry sample weight)/dry sample weight $\mathrm{x}$ 100

\subsection{RVA Measurements}

A Rapid Viscosity Analyzer RVA-4 (Foss North America, Eden Prairie, MN) was used for measuring pasting properties of unprocessed corn bran and jet-cooked corn bran with or without alkaline treatment. Sample (2.24 g, dry basis) was added to DI water in a RVA canister to make a suspension containing $8 \%$ solids. The suspensions were equilibrated at $30^{\circ} \mathrm{C}$ for $1 \mathrm{~min}$, heated to $95^{\circ} \mathrm{C}$ at a rate of $6.0^{\circ} \mathrm{C} / \mathrm{min}$, maintained at $95^{\circ} \mathrm{C}$ for $5.5 \mathrm{~min}$, and cooled to $50^{\circ} \mathrm{C}$ at rate of $6.0^{\circ} \mathrm{C} / \mathrm{min}$ and held at $50^{\circ} \mathrm{C}$ for $5 \mathrm{~min}$. For all test measurements, a constant paddle rotating speed $(160 \mathrm{rpm})$ was used throughout entire analysis except for the first $10 \mathrm{~s}$ to disperse sample (960 $\mathrm{rpm})$. Each sample was analyzed in duplicate.

\subsection{Statistical Analysis}

Statistical differences were calculated using SAS software [22]. A general linear model analysis of variance followed by Tukey's multiple comparison adjustment was used [23]. Significant differences were defined as $p$ $<0.05$.

\section{Results and Discussion}

\subsection{Yield and Compositions}

The soluble solids recovery from $\mathrm{T} 1(\mathrm{pH} \mathrm{12})$ was doubled (Table 1, 38.4\%) compared to soluble solids from T2 (pH 7, 19.4\%), while the insoluble solids (61.6\%) from $\mathrm{T} 1$ were approximately $20 \%$ lower than that in $\mathrm{T} 2$ (81.6\%). T1 included alkali treatment that solubilized a substantial portion of hemicelluloses from plant cell wall materials [24]. Thus, the soluble solids in T1 were increased while insoluble solids were greatly decreased.

The protein content of soluble solids from T2 (Table 1, $6.62 \%$ ) gave the highest among all the fractions. The soluble proteins were apparently a result of high temperature and shearing during jet-cooking. It suggested that high shearing and temperature using jet-cooking under neutral conditions does not degrade protein but increases protein solubility.

The oil contents in soluble $(0.39 \%)$ and insoluble solids $(0.17 \%)$ were decreased significantly from jet-cooking with alkaline treatment (T1) compared with the soluble (1.44\%) and insoluble solids (0.62\%) from T2 with

Table 1. Protein, oil, and ash contents.

\begin{tabular}{cccc}
\hline Treatment & Yield $\%$ & Protein $\%$ & Oil\% $\%$ \\
T1 (pH 12)-soluble & 38.4 & $4.88 \pm 0.48 \mathrm{abc}$ & $0.39 \pm .001 \mathrm{~cd}$ \\
T1(pH 12)-insoluble & 61.6 & $4.33 \pm 0.37 \mathrm{bc}$ & $0.17 \pm 0.12 \mathrm{~d}$ \\
T2-(pH 7)soluble & 19.4 & $6.23 \pm 0.34 \mathrm{a}$ & $1.44 \pm 0.01 \mathrm{a}$ \\
T2-(pH 7) insoluble & 81.6 & $4.00 \pm 0.64 \mathrm{c}$ & $0.62 \pm 0.04 \mathrm{c}$ \\
TC-starting material & 100 & $5.80 \pm 0.11 \mathrm{ab}$ & $1.31 \pm 0.36 \mathrm{~cd}$ \\
\hline
\end{tabular}

Reported as mean \pm standard deviation $(n=3)$ on dry base; the values with different letters within column indicate significant differences $(p<0.05)$. 
out alkaline treatment, and TC starting material $(1.02 \%$, Table 1). The high $\mathrm{pH}$ could have resulted in the degradation of lipids in T1. The oil content of soluble solids from T2 was highest (1.44\%) among all the samples, about $30 \%$ higher compare with starting corn bran $(1.02 \%)$. Jet-cooking of T2 greatly modified the structure of corn bran by its high shear and high temperature, but did not degrade the oil and protein. Also, the oil content of soluble solids was significantly increased in T2 since the total weight was decreased by removing insoluble materials by centrifugation.

The ash contents of all treated fractions were higher than that of TC, unprocessed corn bran (Table 1). The ash contents $(39.88 \%)$ from $\mathrm{T} 1$ were significantly higher than that of TC $(1.09 \%)$. It was likely due to lime added in the beginning of the processing for $\mathrm{T} 1$, and could also provide a nutritional source of calcium.

The fatty acid composition was indicative of corn oil [25]. All samples contained a predominance of oleic acid, followed by linoleic acid (Table 2) with exception of insoluble solids from T2. The un-saturated/saturated ratio from T1 was higher than that from T2 and TC. Thus, T1 had less saturated fatty acids in the soluble solids compared to T2 and TC. The fatty acid content from T1 in- soluble solids was below detention limit that may be due to the extremely low oil content $(0.17 \%)$.

\subsection{Total Phenolic Content}

Phenolics are commonly categorized as phenolic acids, flavonoids, stilbenes, coumarins, and tannins. Phenolics are the products of secondary metabolism in plants, providing essential functions in the reproduction and growth of the plants, acting as defense mechanisms against pathogens, parasites, and predators, as well as contributing to the color of plant. In addition to their roles in plants, phenolic compounds in our diet may provide health benefits associated with reduced risk of chronic diseases [26].

\subsubsection{Effect of Alkaline Treatments}

The phenolic contents from $\mathrm{T} 1$ in soluble solids (56.30, $61.38,54.25$ and $52.93 \mathrm{mg} / \mathrm{g}$ ) were highest among all samples regardless solvent (Table 3). The phenolic contents from T1 in insoluble solids $(28.76,31.14,29.74$, $28.12 \mathrm{mg} / \mathrm{g}$.) were about half compared to soluble solids in T1, but they were significantly higher than soluble and insoluble solids in T2 and TC for all solvents used with exception for $0.2 \% \mathrm{Ca}(\mathrm{OH})_{2}$ extraction of insoluble so-

Table 2. Fatty acid compositions.

\begin{tabular}{|c|c|c|c|c|c|c|}
\hline & \multirow{2}{*}{$\begin{array}{l}\text { Unsaturated } \\
\text { Satturated }\end{array}$} & \multicolumn{2}{|c|}{ Saturated } & \multirow{2}{*}{$\begin{array}{c}\text { Mono-unsaturated } \\
\text { Oleic }\end{array}$} & \multicolumn{2}{|c|}{ Poly-uunsaturated } \\
\hline & & Palmitic & Stearic & & Linoleic & Linoienic \\
\hline $\mathrm{T} 1(\mathrm{pH} 12)$-soluble & 9.9 & 6.74 & 2.42 & 65.11 & 19.88 & 5.85 \\
\hline T1(pH 12)-insoluble & & - & - & - & - & - \\
\hline T2(pH 7)-soluble & 7.8 & 9.29 & 2.02 & 56.79 & 27.4 & 4.5 \\
\hline T2(pH 7)-insoluble & 4.3 & 15.83 & 2.95 & 46.85 & 32.63 & 1.73 \\
\hline TC-starting martial & 5.7 & 13.01 & 1.9 & 26.72 & 54.4 & 3.97 \\
\hline
\end{tabular}

Under detection limit.

Table 3. Phenolic contents extracted by water, $10 \%$ and $50 \%$ ethanol.

\begin{tabular}{ccccc}
\hline Treatment & Water & $10 \%$ Ethanol & $50 \%$ Ethanol & $0.2 \% \mathrm{Ca}(\mathrm{OH})_{2}$ \\
\cline { 2 - 5 } & $\mathrm{mg} / \mathrm{g}$ & $\mathrm{mg} / \mathrm{g}$ & $\mathrm{mg} / \mathrm{g}$ & $\mathrm{mg} / \mathrm{g}$ \\
\hline T1 (pH 12)-soluble & $56.30 \pm 0.39^{\mathrm{A}(\mathrm{ab})}$ & $61.38 \pm 3.65^{\mathrm{A}(\mathrm{a})}$ & $54.25 \pm 0.41^{\mathrm{A}(\mathrm{ab})}$ & $52.93 \pm 1.21^{\mathrm{A}(\mathrm{b})}$ \\
T1 (pH 12)-insoluble & $28.76 \pm 1.08^{\mathrm{B}(\mathrm{ab})}$ & $31.14 \pm 0.00^{\mathrm{B}(\mathrm{a})}$ & $29.74 \pm 0.53^{\mathrm{B}(\mathrm{ab})}$ & $28.12 \pm 0.36^{\mathrm{B}(\mathrm{b})}$ \\
T2-(pH 7)soluble & $7.18 \pm 0.23^{\mathrm{C}(\mathrm{ab})}$ & $7.10 \pm 0.06^{\mathrm{C}(\mathrm{ab})}$ & $6.85 \pm 0.18^{\mathrm{C}(\mathrm{b})}$ & $7.83 \pm 0.35^{\mathrm{D}(\mathrm{a})}$ \\
T2-(pH 7)insoluble & $0.92 \pm 0.05^{\mathrm{D}(\mathrm{d})}$ & $2.18 \pm 0.06^{\mathrm{C}(\mathrm{c})}$ & $3.50 \pm 0.12^{\mathrm{D}(\mathrm{b})}$ & $26.76 \pm 0.06^{\mathrm{B}(\mathrm{a})}$ \\
TC-starting material & $1.28 \pm 0.11^{\mathrm{D}(\mathrm{d})}$ & $2.79 \pm 0.13^{\mathrm{C}(\mathrm{c})}$ & $4.64 \pm 0.19^{\mathrm{D}(\mathrm{b})}$ & $23.57 \pm 0.06^{\mathrm{C}(\mathrm{a})}$ \\
\hline
\end{tabular}

Date reported in mg gallic acid per g on dry base (mean \pm standard deviation, $n=3$ ); the like Cap-case letters within column, or the like low-case letters in parenthesis within row indicate significant difference $(p<0.05)$. 
lids from T2 (Table 3). The phenolic contents from T2 in soluble solids $(7.18,7.10,6.85,7.83 \mathrm{mg} / \mathrm{g})$, using all solvents respectively, were less than $20 \%$ of that from soluble solids from T1 $(56.30,61.38,54.25$ and 52.93 $\mathrm{mg} / \mathrm{g}$ ). It indicated that alkaline conditions were effective in degrading the cell wall structure of corn bran in $\mathrm{T} 1$; hence, phenolic compounds, such as ferulic acid, could be released from ester bonds by alkaline conditions [27]. Overall, the phenolic contents were higher in soluble solids than insoluble solids regardless treatment with the exclusion of the extractions by $0.2 \% \mathrm{Ca}(\mathrm{OH})_{2}$. Phenolic contents $(7.18,7.10,6.85$, and $7.83 \mathrm{mg} / \mathrm{g})$ in soluble solids from T2 ( $\mathrm{pH} 7$ ) using different solvents, respectively, were higher than that $(1.28,2.79,4.64$, and $23.57 \mathrm{mg} / \mathrm{g})$ from TC. Food processing, such as thermal processing, pasteurization, fermentation, and freezing, contributes to the release of bound phenolic acids [4]. In general, the phenolic contents of soluble and insoluble solids from T1 with alkaline treatment were significantly higher than those from T2 and TC. Our study indicated that high temperature and shearing by jet-cooking released some soluble phenolic compounds, but alkaline treatment and jet-cooking together was the most effective procedure to release phenolic compounds from corn bran.

\subsubsection{Effect of Ethanol Concentration}

Ten percent ethanol was chosen because it was generally the concentration used for preparing standards in a typical procedure [16]. The phenolic contents in insoluble solids from T2 and TC were significantly increased with increasing ethanol percentage (Table 3). It suggests that phenolic compounds from corn bran have a high solubility in ethanol. There were no significant differences found in insoluble and soluble solids from T1 by different concentrations of ethanol respectively (Table 3). It suggests that the effect of alkaline condition on phenolic solubility was more effective than ethanol concentration for extraction.

\subsubsection{Effect of $0.2 \% \mathrm{Ca}(\mathrm{OH})_{2}$ Extraction}

Interestingly, dramatic increases in phenolic contents were found in solids from T2 and TC $(23.57 \mathrm{mg} / \mathrm{g})$ using $0.2 \% \mathrm{Ca}(\mathrm{OH})_{2}$, compared to water, $10 \%$ and $50 \%$ ethanol extractions, respectively. There are bound phenolic content and free phenolic content and the contribution of bound phenolic to the total phenolic content was significantly higher than that of free and esterfied fractions [28]. The solids from T2 and TC were not involved with alkaline treatment. Therefore, bound phenolic compounds from $\mathrm{T} 2$ and $\mathrm{TC}$ were released using when $0.2 \%$ calcium hydroxide. There were no significant differences in phenolic contents for soluble and insoluble solids from $\mathrm{T} 1$ between water extraction and $0.2 \%$ calcium hydroxide extraction $(56.30 \mathrm{mg} / \mathrm{g}$ vs. $52.93 \mathrm{mg} / \mathrm{g}$, and $28.76 \mathrm{mg} / \mathrm{g}$ vs. $28.12 \mathrm{mg} / \mathrm{g}$ since the solids from T1 were processed under alkaline conditions previously. Probably most bound phenolic compounds in T1 were released from cell wall structures by alkaline treatment and found in free form after processing. Therefore, $0.2 \%$ calcium hydroxide extraction had no effect on results.

Our results confirmed that alkaline conditions are important for the release phenolic compounds. Also, it is possible to extract more phenolic com-pounds from insoluble solids without alkaline treat-ment and TC by using alkaline extraction such as $0.2 \%$ calcium hydroxide. Perhaps the $0.2 \%$ calcium hydroxide extraction could be an alternative and efficient choice without jet-cooking for extracting increased amount of phenolic compounds.

\subsubsection{The Comparison of Gallic Acid and Ferulic Acid as Standards for Phenolic Analysis}

Ferulic acid plays a significant role in the plant cell walls because it forms bonding between polysaccharides and proteins [27]. Ferulic acid is a well known antioxidant with potential for food and medical applications [29]. Gallic acid is commonly used for phenolic content test. This study was the first report using ferulic acid as standard to determine phenolic content in corn bran. The statistical significant differences were found in soluble solids of $\mathrm{T} 1$, insoluble solids of $\mathrm{T} 2$, and $\mathrm{TC}$ between the results using gallic acid or ferulic acid as standard (Table 4). The results from this study provided an alternative choice for using ferulic acid as standard to test phenolic content.

\subsection{Identification of Phenolic Acids Using HPLC}

To further indentify phenolic acids in each of the corn bran fractions, HPLC was used to detect caffeic, coumaric and ferulic acid, three of the most common phenolic acids in corn [30]. The coumaric, caffeic, ferulic and sinapic acids are mainly present in the bound form, linked to cell wall components such as cellulose, lignin, and proteins through ester bonds [26]. Their structures are similar, except on carbon 3 of the phenolic ring, ferulic acid has methyl ether, caffeic acid has a hydroxyl group, and coumaric acid has hydrogen. The extra hydroxyl group on caffeic acid makes it more water-soluble than coumaric and ferulic acids [12]. The soluble solids from $\mathrm{T} 1 \mathrm{had}$ the highest coumaric content $(0.933 \mathrm{mg} / \mathrm{g})$ and ferulic acid content $(7.153 \mathrm{mg} / \mathrm{g})$ among all the samples tested (Table 5). Consistent with the total phenolics data, in general, the soluble fractions after treatment had higher phenolic acid levels than the insoluble fractions in T1. The trend for coumaric and ferulic acid content using LC-ESI-MS were in agreement with the total phenolic contents measured by spectrophotometer. The results were comparable with a previous study that considerable 
Table 4. Phenolic contents of $50 \%$ ethanol extracts.

\begin{tabular}{ccc}
\hline Treatment & Gallic acid (mg/g) & Ferulic acid (mg/g) \\
\hline T1 (pH 12)-soluble & $54.25 \pm 0.41 \mathrm{~b}$ & $60.68 \pm 0.51 \mathrm{a}$ \\
T1(pH 12)-insoluble & $29.74 \pm 0.53 \mathrm{a}$ & $33.00 \pm 1.73 \mathrm{a}$ \\
T2 $(\mathrm{pH}$ 7)-soluble & $6.85 \pm 0.18 \mathrm{a}$ & $6.71 \pm 0.26 \mathrm{a}$ \\
T2(pH 7)-insoluble & $3.5 \pm 0.12 \mathrm{a}$ & $1.10 \pm 0.07 \mathrm{~b}$ \\
TC-starting material & $4.64 \pm 0.19 \mathrm{a}$ & $2.23 \pm 0.07 \mathrm{~b}$ \\
\hline
\end{tabular}

Using gallic acid or ferulic acid as standard reported in $\mathrm{mg}$ of gallic acid equivalents or ferulic acid per $\mathrm{g}$ on dry base (mean \pm standard deviation, $n=3$ ); the values with different letters within row indicate significant differences $(p<0.05)$.

Table 5. Phenolic acid contents using LC-ESI-MS.

\begin{tabular}{|c|c|c|c|}
\hline Treatment & Caffeic (mg/g) & Coumaric $(\mathrm{mg} / \mathrm{g})$ & Ferulic (mg/g) \\
\hline $\mathrm{T} 1$ (pH 12)-soluble & $0.058 \pm 0.002 \mathrm{~b}$ & $0.933 \pm 0.041 \mathrm{a}$ & $7.153 \pm 0.295 \mathrm{a}$ \\
\hline $\mathrm{T} 1(\mathrm{pH} 12)$-insoluble & $0.064 \pm 0.002 \mathrm{a}$ & $0.298 \pm 0.020 \mathrm{~b}$ & $2.667 \pm 0.160 \mathrm{~b}$ \\
\hline T2(pH 7)-soluble & $0.000 \mathrm{c}$ & $0.000 \mathrm{c}$ & $0.047 \pm 0.008 \mathrm{c}$ \\
\hline T2(pH 7)-insoluble & $0.000 \mathrm{c}$ & $0.000 \mathrm{c}$ & $0.000 \mathrm{c}$ \\
\hline TC-starting material & $0.059 \pm 0.002 \mathrm{a}$ & $0.023 \pm 0.003 \mathrm{c}$ & $0.041 \pm 0.008 \mathrm{c}$ \\
\hline
\end{tabular}

Reported in mg per $\mathrm{g}$ on dry base (mean \pm standard deviation, $n=3)$; the like letters within column indicate significant difference $(p<0.05)$.

amounts of hydroxycinnamic acid (up to $0.015 \%$ of mainly ferulic acid) and lipid (up to $0.043 \%$ ) were released with $1.5 \mathrm{~N}$ methanolic $\mathrm{KOH}$ [31]. The higher coumaric and ferulic acid levels were found in the soluble fraction from alkaline treatment while the soluble fraction without alkaline treatment contained much lower level of these phenolic acids. These phenolic acids were liberated through base-catalyzed hydrolysis during processing in $\mathrm{T} 1$ suggesting that $\mathrm{T} 1$ was more effective at liberating water-soluble phenolic acids than T2. Our results indicated that colorimetric method using spectrophotometer was suitable to determine total phenolic acid compounds while LC-ESI-MS was excellent for identifying the individual phenolic compound.

\subsection{Antioxidant Activity}

The antioxidant activities of soluble solids from T2 (6.49, 5.68 , and $6.87 \mu \mathrm{mol} / \mathrm{g}$ ) were the highest among all fractions regardless of extracting solvent and treatment (Table 6). It was not expected that the soluble solids from $\mathrm{T} 1$ would have the highest phenolic content but without increasing antioxidant activities, regardless of solvent. T1 included harsher conditions (high temperature, pressure, and high $\mathrm{pH}$ ) than $\mathrm{T} 2$ which may have destroyed some antioxidant activity of the phenolics. Perhaps those phenolics having a greater number of hydroxyl-type substituents may be more easily degraded under the alkaline extraction conditions whereas some phenolics without antioxidant activity appear to be more stable than those with antioxidant activity [32].

Significant differences in antioxidant activities were observed between water and 50\% ethanolic extracts. Over all, antioxidant activities were increased with increasing ethanol percentages. Fifty \% ethanol extracts showed significantly higher anti-oxidant activity in all cases. Trolox has lower water solubility $(0.5 \mathrm{mg} / 1 \mathrm{~mL})$ than that of gallic acid (11.5 mg / $1 \mathrm{~mL}$, Merck Index), indicating that the phenolic compounds exhibiting antioxidant activities had high solubility in ethanol. T2 gave enhanced antioxidant activities in the soluble fraction compared to TC (Table 6).

\subsection{Water Holding}

Jet-cooking increased water holding capacities from $254 \%$ (TC) to about $300 \%$ for jet-cooked solids without $\mathrm{pH}$ adjustment (T2). As the $\mathrm{pH}$ values were adjusted to 12 prior to jet-cooking (T1), the water holding capacity of insoluble solids was considerably increased to $524 \%$ (Figure 1). The results of water holding capacities were consistent with the data obtained from peak viscosity using Rapid viscosity analysis (Figure 2). The results were consistent with the previous research that thermomechanical shear during steam jet-cooking led to significant increases in the water absorption, water solubility, and swelling power of the barley flour [33] and earlier research on corn bran $[9,10]$. 
Table 6. Antioxidant activities of water, $10 \%$ and $50 \%$ ethanol extracts.

\begin{tabular}{rccc}
\hline Treatment & Water $(\mu \mathrm{mol} / \mathrm{g})$ & $10 \% \mathrm{EtOH}(\mu \mathrm{mol} / \mathrm{g})$ & $50 \% \mathrm{EtOH}(\mu \mathrm{mol} / \mathrm{g})$ \\
\hline T1 (pH 12)-soluble & $0.00 \pm 0.00^{\mathrm{C(c)}}$ & $1.85 \pm 0.00^{\mathrm{D}(\mathrm{b})}$ & $2.84 \pm 0.04^{\mathrm{E}(\mathrm{a})}$ \\
T1 (pH 12)-insoluble & $3.53 \pm 0.03^{\mathrm{B(b)}}$ & $4.08 \pm 0.11^{\mathrm{CB}(\mathrm{a})}$ & $4.23 \pm 0.02^{\mathrm{D}(\mathrm{a})}$ \\
T2(pH 7)-soluble & $6.49 \pm 0.01^{\mathrm{A}(\mathrm{b})}$ & $5.68 \pm 0.02^{\mathrm{A}(\mathrm{c})}$ & $6.87 \pm 0.02^{\mathrm{A}(\mathrm{a})}$ \\
T2( $\mathrm{pH}$ 7)-insoluble & $2.32 \pm 0.01^{\mathrm{B}(\mathrm{b})}$ & $3.76 \pm 0.26^{\mathrm{C}(\mathrm{ab})}$ & $4.98 \pm 0.29^{\mathrm{C}(\mathrm{a})}$ \\
TC-starting material & $3.53 \pm 0.03^{\mathrm{B(c)}}$ & $4.59 \pm 0.0^{\mathrm{B}(\mathrm{b})}$ & $5.94 \pm 0.23^{\mathrm{B}(\mathrm{a})}$ \\
\hline
\end{tabular}

Reported in mg gallic acid per g on dry base (mean \pm standard deviation, $n=3$ ); the like Cap-case letters within column, or the like low-case letters in parenthesis within row indicate no significant difference $(p>0.05)$.

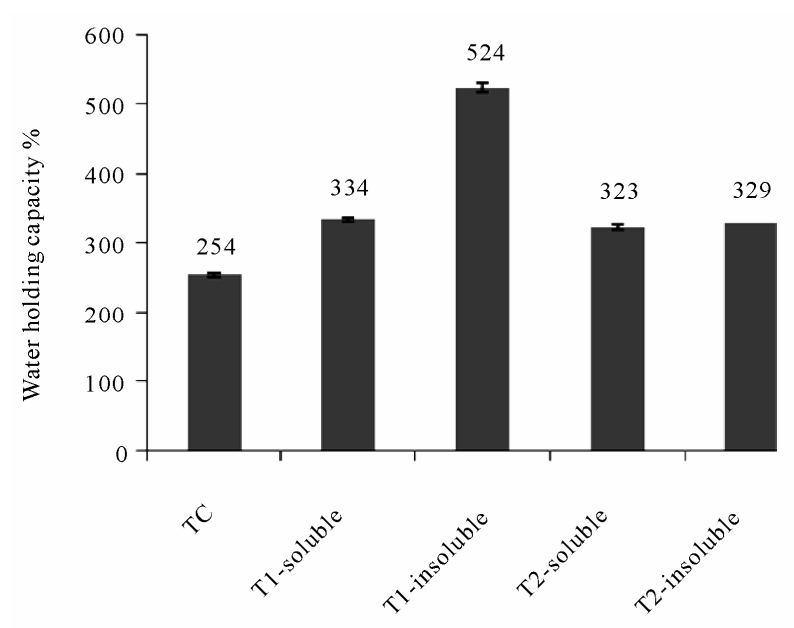

Figure 1. Water holding capacities of jet-cooked corn bran at different $\mathrm{pH}$ values compared with unprocessed corn bran.

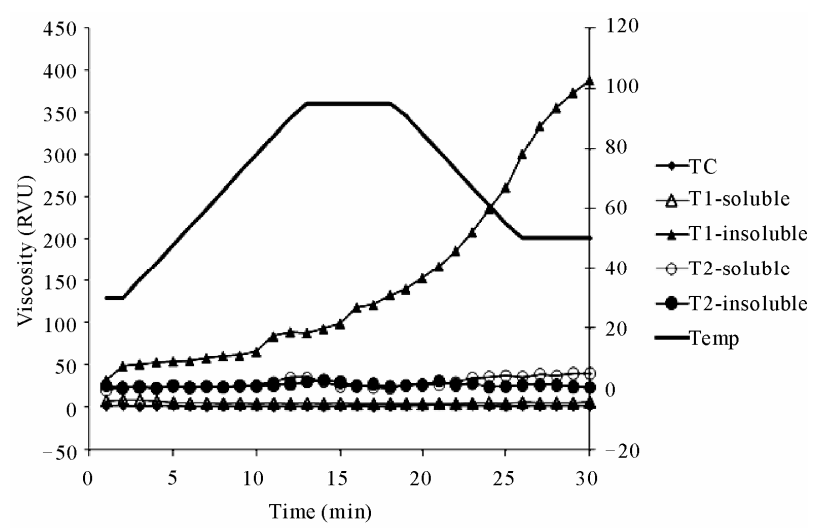

Figure 2. RVA pasting profiles of jet-cooked barley flours at different $\mathrm{pH}$ values compared with unprocessed corn bran.

\subsection{Rapid Viscosity Analysis}

The insoluble solids from T1 demonstrated higher viscosity compared with processed samples from T2 and TC (Figure 2). Apparently, the high $\mathrm{pH}$ degraded cell wall structures in T1, creating more small molecules that resulted in increasing thickness and viscosity. The pasting curve from minimum viscosity after peak to final viscosity, referred to as the setback region, was significantly increased for the insoluble solids with alkaline treatment. A large setback value is generally associated with syneresis, or weeping, during freeze/thaw cycles [34]. This special property along with high antioxidant activities could be an important factor in making functional corn bran products.

\section{Conclusions}

This study demonstrated that jet-cooked corn bran under alkaline conditions (T1) produced more soluble solids with increased total phenolic content and high water holding capacities along with interesting viscoelastic properties but without increasing antioxidant activities. Jet-cooking corn bran without alkali (T2) increased the soluble solids that contained higher phenolic content with increased antioxidant activity and water holding capacity compared with control (TC). This study suggested that corn bran is an important source of phytochemicals including phenolics having antioxidant activities. The jetcooking technology may increase the value of corn bran by creating new photochemical and functional products.

\section{REFERENCES}

[1] R. A. Moreau, A. Nuñez and V. Singh, "Diferuloylputrescine and $P$-Coumaroyl-Feruloylputrescine, Abundant Polyamine Conjugates in Lipid Extracts of Maize Kernels," Lipids, Vol. 36, No. 8, 2001, pp. 839-844. doi:10.1007/s11745-001-0793-6

[2] M. J. Kim, S. M. Kim, K. R. Im and K.-S. Yoon, "Effect of Hydroxycinnamic Acid Derivatives from Corn Bran on Melanogenic Protein Expression," Journal of the Korean Society for Applied Biological Chemistry, Vol. 53, No. 4, 2010, pp. 422-426.

[3] A. Y. A. Plate and D. D. Gallaher, "The Potential Health Benefits of Corn Components and Products," Cereal Foods World, Vol. 50, No. 6, 2005, pp. 305-314.

[4] V. Dawanto, X. Z. Wu and R. H. Liu, "Processed Sweet 
Corn has Higher Antioxidant Activity," Journal of Agricultural and Food Chemistry, Vol. 50, 2002, pp. 4959-4964. doi:10.1021/jf0255937

[5] Z. Liu, J. Wang, P. Shen, C. Wang and Y. Shen, "Microwave-Assisted Extraction and High-Speed Counter-Current Chromatography Purification of Ferulic Acid from Radix Angelicae Sinensis," Separation and Purification Technology, Vol. 52, No. 1, 2006, pp.18-21. doi:10.1016/i.seppur.2006.03.009

[6] A. Wolk, J. E. Manson, M. J. Stampfer, G. A. Colditz, F. B. Hu, F. E. Speizer, C. H. Hennekens, and W. C. Willett, "Long-Term Intake of Dietary Fiber and Decreased Risk of Coronary Heart Disease among Women," Journal of the American Medical Association, Vol. 281, No. 21, 1999, pp. 1998-2004. doi:10.1001/jama.281.21.1998

[7] B. Wang, B. Cheng and F. Hao, "Enrich Arabinnoxylan in corn Fiber for Value-Added Products," Biotechnology Letters, Vol. 30. No. 2, 2007, pp. 275-279. doi:10.1007/s10529-007-9537-9

[8] M. P. Yadav, D. B. Johnston, Jr., A. T. Hotchkiss and K. B. Hicks, "Corn Fiber Gum: A Potential Gum Arabic Replacer for Beverage Flavor Emulsification," Food Hydrocolloids, Vol. 21, No. 7, 2007, pp. 1022-1030. doi:10.1016/j.foodhyd. 2006.07.009

[9] G. E. Inglett, "Development of a Dietary Fiber Gel for Calorie-Reduced Foods," Cereal Foods World, Vol. 42, No. 5, 1997, pp. 382-385.

[10] G. E. Inglett, "Soluble Hydrocolloid Food Additives and Method of Making," US Patent No. 6,060,519. 1998.

[11] D. N. Kim, I. Y. Bae, G. E. Inglett and S. Lee, "Effects of Hydrothermal Treatment on the Physicochemical, Rheological and Oil-Resistant Properties of Rice Flour," Journal of Texture Studies, Vol. 40, No. 2, 2009, pp. 192-207. doi:10.1111/j.1745-4603.2009.00176.x

[12] G. E. Inglett, D. Chen, D. J. Rose and M. Berhow, "High-Shear, Jet-Cooking, and Alkali Treatment of Corn Distillers Dried Grains to Obtain Products with Enhanced Protein, Oil and Phenolic Antioxidants," Food Science and Technology International, Vol. 16, No. 4, 2010, pp. 297-304. doi:10.1177/1082013209353821

[13] AACC International, "Approved Methods of Analysis," 11th Edition, AACC International, St. Paul, 2010.

[14] American Association of Cereal Chemists, "Crude Protein-Combustion Method," In: "American Association of Cereal Chemists Official Methods," 9th Edition, St. Paul, 1995, pp. 46-30.

[15] American Oil Chemists' Society, “Official Methods and Recommended Practices of the American Oil Chemists Society," 4th Edition, Champaign, 1993, pp. 3-44.

[16] A. L. Waterhouse, "Determination of Total Phenolics," In R. E. Wrolstad, Ed., Current Protocols in Food Analytical Chemistry, John Wiley \& Sons, Inc., New York, 2001.

[17] L. Yu and K. Zhou, "Antioxidant Properties of Bran Extracts from 'Platte' Wheat Grown at Different Locations," Food Chemistry, Vol. 90, No. 1-2, 2005, pp. 311-316. doi:10.1016/j.foodchem.2004.04.007
[18] W. Brand-Williams, M. E. Cuvelier and C. Berset, "Use of a Free Radical Method to Evaluate Antioxidant Activity," LWT - Food Science and Technology, Vol. 28, No. 1, 1995, pp. 25-30. doi:10.1016/S0023-6438(95)80008-5

[19] I. Sensoy, R. T. Rosen, C.-T. Ho and M. V. Karwe, "Effect of Processing on Buckwheat Phenolics and Antioxidant Activity," Food Chemistry, Vol. 99, No. 2, 2006, pp. 388-393. doi:10.1016/j.foodchem.2005.08.007

[20] M. A. Berhow, “ Modern Analytical Techniques for Flavonoid Determination," In: B. S. Buslig and J. A. Manthey, Eds., Flavonoids in the Living Cell, Kluwer Academic/Plenum Publishers, New York, 2002, pp. 61-76.

[21] B. I. O. Ade-Omowaye, K. A. Taiwo, N. M. Eshtiaghi, A. Angersbach and D. Knorr, "Comparative Evaluation of the Effects of Pulsed Electric Field and Freezing on Cell Membrane Permeabilisation and Mass Transfer during Dehydration of Red Bell Peppers," Innovative Food Science and Emerging Technologies, Vol. 4, No. 2, 2003, pp. 177-188. doi:10.1016/S1466-8564(03)00020-1

[22] SAS Institute Inc., "The SAS ${ }^{\circledR}$ System for Windows ${ }^{\circledR}$," Version 8e, Cary, 1999.

[23] J. W. Tukey, "Where should multiple com-parisons go next?" In: F. M. Hoppe, Ed., Multiple Comparisons, Selection, and Applications in Biometry, New York, 1993, pp. 187-208.

[24] L. W. Doner and K. B. Hicks, "Isolation of Hemicellulose from Corn Fiber by Alkaline Hydrogen Peroxide Extraction," Cereal Chemistry, Vol. 74, No. 2 1997, pp. 176-181. doi:10.1094/CCHEM.1997.74.2.176

[25] P. J. White and E. J. Weber, "Lipids of the kernel," In: P. J. White and L. A. Johnson, Eds, Corn: Chemistry and Technology, American Association of Cereal Chemists, St. Paul, 2003, pp. 355-406.

[26] R. H. Liu, "Whole Grain Phytochemicals and Health," Journal of Cereal Science, Vol. 46, No. 3, 2007, pp. 207-219. doi:10.1016/j.jcs.2007.06.010

[27] P. Jankovska, J. Copikova, A. Sinitsya and M. Novotna, "The Effect of Ferulic Acid on the Structure of Plant Cell Wall and Its Determination," Czech-Journal-of-FoodScience, Vol. 18, 2000, pp. 182-183.

[28] C. M. Liyana-Pathirana and F. Shahidi, "Importance of Insoluble-Bound Phenolics to Antioxidant Properties of Wheat," Journal of Agricultural Food Chemistry, Vol. 54, No. 4, 2006, pp. 1256-1264. doi:10.1021/jf052556h

[29] H. D. Shin, S. McClendon, T. Le, F. Taylor and R. R. Chen, "A Complete Enzymatic Recovery of Ferulic Acid from Corn Residues with Extra-Cellular Enzymes from Neosartorya Spinosa NRRL185," Biotechnology and Bioengineering, Vol. 95, No. 6, 2006, pp. 1108-1115. doi:10.1002/bit.21056

[30] P. Mattila, J.-M. Pihlava and J. Hellstrom, "Contents of Phenolic Acids, Alkyl- and Alkenylresorcinols, and Avenanthramides in Commercial Grain Products," Journal of Agricultural and Food Chemistry, Vol. 53, No. 21, 2005, pp. 8290-8295. doi:10.1021/jf051437z

[31] M. P. Yadav, R. A. Moreau and K. B. Hick, "Phenolic Acids, and Proteins Associated with Purified Corn Fiber 
Arabinoxylans," Journal of Agricultural and Food Chemistry, Vol. 55, No. 3, 2007, pp. 943-947.

doi:10.1021/if0624493

[32] A. Liazid, M. Palma, J. Brigui and C. G. Barroso, "Investigation on Phenolic Compounds Stability during Microwave-Assisted Extraction," Journal of Chromatography $A$, Vol. 1140, 2007, No. 1-2, pp. 29-34.

doi:10.1016/j.chroma.2006.11.040
[33] S. Y. Lee and G. E. Inglett, "Functional Characterization of Steam Jet-Cooked $\beta$-Glucan-Rich Barley Flour as an Oil Barrier in Frying Batters," Journal of Food Science, Vol. 71, No. 6, 2006, pp. E308-E313. doi:10.1111/j.1750-3841.2006.00121.x

[34] Newport Scientific Pty. Ltd., "The Application Manual for the Rapid Visco Analyser," NSW 2102, Warrriewood, 1998. 